\title{
Sprawozdanie z Międzynarodowej Konferencji Naukowej "Republicyzacja zadań publicznych", Poznań, 9 czerwca 2017 r.
}

Konferencja została zorganizowana przez Katedrę Prawa Administracyjnego i Nauki o Administracji we współpracy z Katedrą Publicznego Prawa Gospodarczego Uniwersytetu im. Adama Mickiewicza w Poznaniu. Inicjatorem tego wydarzenia był kierownik Katedry Prawa Administracyjnego i Nauki o Administracji prof. zw. dr hab. Marek Szewczyk, który zaprosił przedstawicieli Uniwersytetu Poczdamskiego do podjęcia współpracy w ramach wspólnej konferencji. Na zaproszenie odpowiedział prof. dr Hartmut Bauer oraz jego współpracownicy - ass. iur. Wolfgang Abromeit i ass. iur. Michael Meier, LL.B.

Tematyka konferencji dotyczyła niezwykle ważnego i aktualnego zjawiska, jakim jest republicyzacja (tj. ponowne upublicznienie) zadań państwowych, których wykonywanie zostało powierzone podmiotom prywatnym. W Niemczech obserwuje się odwrót od prywatyzacji zarówno na poziomie lokalnym, jak i centralnym. W Polsce zjawisko republicyzacji również staje się coraz powszechniejsze, stąd powstała potrzeba zaczerpnięcia z wiedzy i doświadczenia niemieckich przedstawicieli nauki. Pomocą w wymianie myśli i poglądów podczas spotkania służyła tłumaczka języka niemieckiego, pani Kwiryna Kuźmar.

Konferencję otworzył prodziekan ds. nauki i współpracy z zagranicą Wydziału Prawa i Administracji prof. UAM dr hab. Tomasz Nieborak. Podkreślił on wartość międzynarodowych inicjatyw, w tym konferencji, które umożliwiają bezpośrednią wymianę poglądów pomiędzy ośrodkami naukowymi z różnych państw. Jednocześnie została wyrażona nadzieja na dalszy rozwój współpracy pomiędzy Uniwersytetem im. Adama Mickiewicza w Poznaniu a Uniwersytetem Poczdamskim. Prodziekan przywitał gości w języku polskim i niemieckim.

Po oficjalnym przywitaniu uczestników także przez pomysłodawcę konferencji, prof. Marka Szewczyka, przyszedł czas na wygłoszenie referatów.

Pierwszą część konferencji moderował prof. UAM dr hab. Krystian Ziemski, który na wstępie podkreślił, że prywatyzacja zadań publicznych w polskiej rzeczywistości nie zawsze przynosi korzystne efekty. Za przykład posłużyła budowa autostrad $\mathrm{w}$ formule partnerstwa publiczno-prywatnego, która ostatecznie spowodowała wysokie koszty eksploatacji tych dróg. Moderator wyznał, że z ciekawością oczekuje na referaty niemieckich naukowców, aby wyciągnąć z nich wnioski, które - na co liczy - będzie można wykorzystać w polskim systemie prawnym. 
Panel rozpoczął prof. dr Hartmut Bauer, który wygłosił referat pt. „Praxis und Programmatik der Publizisierung: Die Rückkehr des Öffentlichen". Wystąpienie dotyczyło praktyki i perspektyw rozwoju republicyzacji w Niemczech. Na wstępie prof. Bauer wyjaśnił, że przyczynkiem do wyboru tematu referatu stała się jego podróż z Niemiec do Polski autostradą. Opłata za przejazd na odcinkach drogi o porównywalnej długości była diametralnie różna. Ten stan rzeczy okazał się zależny od typu podmiotu, który wybudował dany odcinek autostrady - odcinki wybudowane przez państwo były tańsze, natomiast odcinki wybudowane przy współudziale koncesjonariuszy prywatnych droższe.

Referent wskazał, że w Niemczech obserwuje się odwrót od prywatyzacji na rzecz republicyzacji zadań państwowych. Wynika to z kilku przyczyn. Jedną z nich jest nieskuteczność umów partnerstwa publiczno-prywatnego (dalej: PPP). Umowy te są bardzo skomplikowane i rozbudowane treściowo, a efekty ich zawierania nie są zadowalające dla państwa i jego obywateli. Przykładowo, po zawarciu umowy PPP nastąpiły podwyżki cen wody, ścieków, gazu, ale także podwyższeniu uległy np. opłaty za usługi medyczne. Najbardziej dotkliwa była podwyżka ceny wody, która najpierw wzrosła o 50\%, a ostatecznie osiągnęła wysokość $140 \%$ w stosunku do ceny pierwotnej, sprzed prywatyzacji tego sektora. Obywatele niemieccy przeprowadzili protest dotyczący prywatyzacji z żądaniem referendum w tej sprawie. Prof. Bauer podkreślił, że podobne, negatywne tendencje zaobserwowano na poziomie centralnym. W wyniku powyższego wiele $\mathrm{z}$ zadań państwowych ponownie trafiło do sektora publicznego. Okazało się bowiem, że podmioty publiczne częstokroć świadczą usługi lepszej jakości i tańsze. Ponadto nastąpił znaczny spadek zaufania obywateli do wydajności rynku wskutek nieudanych prywatyzacji. Taki stan rzeczy doprowadził do powszechności republicyzacji w Niemczech.

Kolejny referat pt. „Public Private Partnerships auf dem Prüfstand der Rechnungshöfe" należał do ass. iur. Michaela Meiera, LL.B. Wystąpienie dotyczyło partnerstwa publiczno-prywatnego w orzecznictwie niemieckiego Trybunału Obrachunkowego. Podstawą weryfikacji funkcjonowania PPP była zasada gospodarności i oszczędności. Trybunał wyraził się krytycznie o umowach PPP zwłaszcza w kontekście wysokich kosztów transakcyjnych, jakie generują.

Trzeci referat zatytułowany "Gestaltungsprobleme bei Public Private Partnership-Verträgen" wygłosił ass. iur. Wolfgang Abromeit, który przedstawił niezwykle ciekawe problemy pojawiające się podczas tworzenia umów PPP. Jednym z nich jest nieprzemyślany podział ryzyka pomiędzy partnerami publicznymi a prywatnymi. Podmioty prywatne niechętnie ponoszą ryzyko związane z wykonywaniem umów PPP, żądając w związku z tym wysokich premii za jego ponoszenie. Kolejnym problemem jest niejasno sformułowana treść umów. Brak przejrzystości dotyczy nawet tak istotnych kwestii, jak określenie rodzaju i zakresu usługi, która ma być wykonana w ramach PPP. Dalsze problemy powodują same regulacje prawne, a dokładniej - ich brak, w zakresie ustalania maksymalnych stawek wynagrodzenia dla podmiotów prywatnych. W efekcie umowy PPP często wytwarzają bardzo wysokie koszty. Kolejnym problemem, jaki wskazał referent, jest sytuacja ogłoszenia upadłości przez spółkę prywatna, która wykonuje zadania publiczne w ramach PPP. W takiej sytuacji sektor publiczny przejmuje wykonywanie zadania, co generuje 
podwójne koszty (wykonanie danego zadania publicznego zostało opłacone przez państwo, ale jego realizacja musi zostać przejęta przez organy publiczne).

Było to ostatnie wystąpienie w pierwszym panelu. Po nim odbyła się dyskusja, a uczestnicy konferencji zgłaszali pytania do prelegentów. Dyskusja trwała jeszcze w kuluarach podczas przerwy na kawę.

Drugą część konferencji rozpoczął referat prof. zw. dr hab. Bożeny Popowskiej, kierownika Katedry Publicznego Prawa Gospodarczego UAM, który został wygłoszony w języku niemieckim. Tematem wystąpienia były „Änderungen der rechtlichen Lösungen im Bereich der ÖPP; die Verstärkung des öffentlich-rechtlichen Aspekts" („Kierunki zmian regulacji prawnej w zakresie partnerstwa publiczno-prywatnego; wzmocnienie aspektu prawa publicznego"). Prelegentka zwróciła uwagę, że ewolucja polskich przepisów dotyczących partnerstwa publiczno-prywatnego pokazuje, iż ważnym elementem wprowadzenia w życie unormowanych prawnie form współpracy jest otoczenie prawne związane z działalnością gospodarczą zarówno w postaci przepisów polskich, jak i unijnych. Referentka swoje rozważania rozpoczęła od ukazania dwóch płaszczyzn prywatyzacji w Polsce, a następnie skupiła się na zagadnieniu jednej z nich, a mianowicie partnerstwa publiczno-prywatnego. Istotny jest bowiem fakt, że rozwiązania prawne wskazują na dominującą pozycję podmiotów publicznych w ramach tej współpracy, a formuła współpracy w ramach umowy PPP niewątpliwie umożliwia realizowanie interesów publicznych. Prelegentka dokonała także analizy rozwiązań projektu ustawy nowelizującej ustawę o partnerstwie publiczno-prywatnym.

Jako następny wystąpił dr Piotr Lissoń z Katedry Publicznego Prawa Gospodarczego UAM, który zaprezentował referat pt. „Komunalizacja i rekomunalizacja zadań w zakresie energetyki w świetle nowych regulacji prawnych". Energetyka jest newralgicznym sektorem gospodarki, który z wielu względów niechętnie był oddawany w ręce prywatne. Przedsiębiorstwa ciepłownicze do czasu transformacji ustrojowej w Polsce funkcjonowały w większości jako przedsiębiorstwa państwowe. Następnie Ustawa z dnia 8 marca 1990 r. o samorządzie terytorialnym określiła, że zaopatrzenie zbiorowych potrzeb wspólnoty należy do zadań własnych gminy, co w szczególności dotyczyło zaopatrzenia w energię, to zaś spowodowało komunalizację przedsiębiorstw ciepłowniczych. Obecnie, jak zasygnalizowano w referacie, widoczne są tendencje odwrotne ze względu na wielorakie aspekty, chociażby finansowe. Korzystniejsze jest powierzenie zadania w postaci dostarczania energii podmiotom publicznym.

Kolejny referat pt. „Nowe czy stare formy prywatyzacji zadań publicznych? Dylematy kształtowania prawnych ram rozwoju elektromobilności w Polsce" zaprezentował mgr Jarosław Kola. Ukształtowanie ram prawnych dla rozwoju elektromobilności w Polsce zostało zdeterminowane przez normy unijne. Państwa członkowskie powinny podjąć wszelkie środki stymulujące rozwój elektromobilności. Prelegent zwrócił uwagę na interesujący na tle projektu ustawy o elektromobilności i paliwach alternatywnych problem w postaci sposobu wyłonienia podmiotu prywatnego, który miałby zbudować infrastrukturę ogólnie dostępnych punktów ładowania. Projektodawcy nie zdecydowali się bowiem na włączenie regulacji wyboru operatora do reżimu zamówień publicznych, co budzi wiele wątpliwości. 
Czwarte wystąpienie w tym panelu zatytułowane "Republicyzacja a koncepcja New Public Management" należało do dr. Marcina Princa z Katedry Prawa Administracyjnego i Nauki o Administracji UAM. Referent skoncentrował się na próbie odpowiedzi na pytanie, czy republicyzacja oznacza zmierzch koncepcji New Public Management czy też nie. W wystąpieniu została także nakreślona koncepcja New Public Service odpowiadająca zjawisku republicyzacji.

Jako przedostatni swoje wystąpienie zaprezentował dr Maciej Kruś, adiunkt w Katedrze Prawa Administracyjnego i Nauki o Administracji UAM. Referat pt. „Zmiany w systemie gospodarki odpadami” został podzielony na trzy części. Pierwsza dotyczyła ujęcia zadania publicznego w postaci gospodarki odpadami ze względu na podmiot odpowiedzialny za odpady. Druga koncentrowała się na podmiotach faktycznie realizujących zadania. Tymi podmiotami były najczęściej sprywatyzowane zakłady, jednakże obecnie widoczna jest tendencja do realizacji tego zadania przez przedsiębiorstwa gminne w trybie zamówień in house. Trzecia część referatu dotyczyła spojrzenia na realizację omawianego zadania z perspektywy mieszkańca gminy. Na przykładzie gospodarowania odpadami widoczna jest tendencja do zwiększania zakresu zadań gminy, a także mająca miejsce republicyzacja tego zadania.

Konferencję zwieńczyło wystąpienie kierownika Katedry Prawa Administracyjnego i Nauki o Administracji UAM prof. zw. dr. hab. Marka Szewczyka, który wygłosił referat w języku niemieckim pt. ,"Republizisierung der Erfüllung der öffentlichen Aufgaben am Beispiel des Baus und Betriebs der gebührenpflichtigen Autobahnen und Schnellstraßen im polnischen Rechtssystem” ("Prywatyzacja i republicyzacja. Zmiany modelu przygotowania i budowy dróg w Polsce"). Wystąienie to wpisuje się szczególnie silnie w problematykę krytycznego spojrzenia na prywatyzację $\mathrm{w}$ realizacji zadania $\mathrm{w}$ postaci budowy autostrad i dróg ekspresowych, w ujęciu zaprezentowanym przez prof. Bauera, a także prof. Ziemskiego. Wystąpienie prof. Szewczyka zamknęła konkluzja, że prywatyzacja zadania budowy i zarządzania autostradami i drogami ekspresowymi, ze względu na koszty eksploatacji tej infrastruktury, jest nieudanym przedsięwzięciem.

Na zakończenie konferencji głos zabrał ponownie prof. Hartmut Bauer, odnosząc się do wystąpień prelegentów, a także dziękując za to wspólne przedsięwzięcie. $W$ otwartej dyskusji pojawiły się liczne pytania do prelegentów, na które to odpowiedzi w szerszym ujęciu udzielone zostaną w publikacji pokonferencyjnej. 